Oxford for building a new college especially for social sciences. Mr. Ramsay MacDonald claimed that close co-operation between the man of science, the industrialist and the man of affairs is needed to assist the changes which diminish the disruptive forces in society and promote the social solidarity lying at the root of human progress. This reminder of the futility of blaming science and scientific workers for the horrors of war is equally timely. Although science has increased the power which can be applied both to life and to death, peace or war are not the responsibility of men of science as such, and they may well claim that by making war more widespread they have driven home the responsibility for warfare, which lies in the moods of man rather than in his mechanical inventions.

\section{The Evolution of Torpedo Craft}

Ir was but natural that in his presidential address to the Institution of Mechanical Engineers on October 22, Sir J. E. Thornycroft should deal with the development of torpedo craft. He was a child five years of age when at Chiswick his father, Sir J. I. Thornycroft (1843-1928) built the Lightning, the first torpedo boat in the British Navy, and he has thus witnessed the growth in size, speed and power of torpedo boats, torpedo boat destroyers and the newest motor torpedo boats. Together with Sir Alfred Yarrow and Jacques-Augustin Normand, of Havre, Sir J. I. Thornycroft was a pioneer of watertube boilers, forced-draught and high-speed engines, and from the works he founded at Chiswick and Woolston have come many of the most notable vessels ever launched. Towards the end of his address, Sir John Thornycroft made some interesting observations on the skimming principle applied to boats, and on the need for simplification in warships. As is well known, the motor torpedo boat, first brought into use in the Great War, is of such a design that when sufficient speed is attained it skims or planes along the surface of the water. Some people think the principle might be applied to larger vessels, but Sir John pointed out that whereas a 50 -ft. motorboat will skim at 30 knots, a 300 -ft. destroyer would have to attain a speed of 70 knots, and this would necessitate engines of 200,000 horse-power. Apart from the propelling machinery, ships to-day are filled with mechanism. The very complexity of this raises the question as to means by which it i.3 to be kept in order, and this led to the suggestion that the work of mechanical engineers should be in the direction of simplification.

\section{Co-ordination of Fuel Interests}

IN his presidential address to the Institute of Fue on October 14, Sir Philip Dawson traversed the whole range of fuel-producing and fuel-using industries, pointing especially to the leakages and inefficiency resulting from the absence of co-ordination between the different interests. Although the different fuels are to a considerable extent complementary, the system of free competition leads to internecine conflict, while desirable goals such as the elimination of smoke and the greater production of liquid fuels receive inadequate attention. Such surveys have often been made in the last fifteen years, and Sir Philip comes, like others before him, to the conclusion that the Government should set up a strong central advisory body to co-ordinate the fuel activities of Great Britain. Hitherto, such proposals have passed unheeded, but now he holds that the national interest demands action. Coal should become the raw material for satisfying modern demands in new form. The future requires a smokeless, pure atmosphere in which to live, and suitable solid, liquid and gaseous fuels for every side of national activities.

\section{The Appraisement of Lighting}

Fon the twenty-second Guthrie Lecture before the Physical Society on October 22, Dr. C. C. Paterson discussed "the Appraisement of lighting". Dr. Paterson pointed out that as techniques have become available during the past thirty years, the art of appraising lighting has changed and advanced greatly. Like so many other subjects, however, that of lighting and seeing has been and is held in check by the inevitable tendency of those who practise it to define it at any epoch in terms of the quantities which they understand. Whereas research can stretch out where it pleases it is difficult for a practical art to advance faster than the established techniques for appraising its merits. The earliest standard ever adopted, specifying a candle of a certain weight in a lantern, is one which has many advantages and which under a changed form is still probably the most widely adopted. The most easily measured characteristic of a light source is luminous intensity, but a measure which is of more value in estimating the aid to seeing is that of luminous flux. With the advent of differently coloured light sources difficulties of such measurements have grown. The adoption of an internationally accepted relative luminosity curve for the average human eye has brought the measurement of intensity of illumination to a high state of accuracy for sources with continuous spectra. The use of the photocell has added to speed and repetitive accuracy, but not to absolute accuracy.

THE measuring of light sources giving a few lines only of the spectrum offers a very much more difficult problem which has been met by the use of sub. standard lamps and carefully selected and calibrated filters. However, with different colours errors creep in. Seeing is fundamentally a matter of contrasts in colour and in brightness, and it is these factors which should be measured. There are several methods of measuring brightness. Photography has been used for registering the effects of lighting on the human eye and recording them permanently on photographic plates. When the brightness of two contrasting surfaces has been measured, we still have no accepted methods of expressing them in terms of their aid to vision. Frichner's fraction, which is an approach in this direction, deals only with threshold values, and our interests lie in values far above those. The new 
technique of television offers an opportunity of controlling contrast. Details of the original picture and the reproduced picture at one stage are both held in terms of electrical energy and can be manipulated. With coloured light our problem is not merely to measure colour, but also to measure and specify colour and colour-rendering properties. The colour of light can readily be specified on the I.C.I. trichromatic system, and a rapid technique for indicating the colour of a light source directly on this system has recently been evolved. No standard has yet, however, been set up for the colour-rendering properties of light.

\section{Devil's Dyke, Wheathampstead}

THE presentation to the public of land at Wheathampstead, which has been made by Lord Brocket, chairman of the Hertfordshire Society of the Council for the Preservation of Rural England, as a personal gift commemorating the coronation of King George and Queen Elizabeth, preserves as an open space in perpetuity a site which, as has been shown by the excavations of Dr. R. E. Mortimer Wheeler, is of outstanding archæological and historical significance. For in addition to the four acres of the prehistoric earthwork, known locally as the Devil's Dyke, as Lord Brocket announced in handing over the 999 years' lease to the Wheathampstead Parish Council on October 23, the adjacent area of one hundred acres will also be preserved as an open space under an arrangement he proposes to make with the Hertfordshire County Council and the National Trust. It was here, Dr. Wheeler has shown, that there was situated the fortress, or oppidum, of more than a hundred acres in extent, the largest and strongest in Britain as yet known in its period, which was held by the Belgic tribes who had settled in Britain not long before, and of which the capture as the headquarters of the British forces was the climax of the campaign. in the second of Cæsar's invasions of Britain; while almost immediately after that event, it would seem, it became the parent city of the British stronghold, also excavated by Dr. Wheeler, at Verulamium, which preceded the Roman occupation. The importance of the site for the history of pre-Roman Britain lays a debt of gratitude to the donor for his gift upon circles far wider than those immediately affected by its preservation of local amenities in the future development of the district.

\section{Archæological Evidence and 'Development'}

IT is unfortunately only too true that in many instances no private benefactor has been available, nor has public interest been sufficiently strong, to save relics of the past thought by many worthy of preservation, as the Wheathampstead site will be preserved. At the same time, land development and public improvement have not invariably run entirely counter to the interests of the archæologist. Not only have they brought to light antiquities of which the existence under the surface of the ground was unsuspected, but also on occasion they have made possible archæological investigations which other- wise it would probably have been impossible to undertake. The exploration of so large a site as that recently excavated at Colchester would have been difficult, if not definitely impossible, had it not been carried out in conjunction with the making of the new road. It is, however, not only the destruction of antiquities that is to be feared. Among other dangers there is the possibility of serious confusion of evidence which may follow the removal of archæological material from one area to another. An instance in point is mentioned by $\mathrm{Mr}$. S. E. Winbolt in a communication to The Times of October 22, in which he records the discovery of a Roman house in the course of widening a road at Wiggonholt near Pulborough. The soil from this site is being transported by lorry to Pulborough Causeway, two and a half miles away. The discovery was made on the site of cottages called Lickfold (cabbage patch); and in the soil have been found fragments of Roman pottery, Samian and Castor, the foot-ring of a large Samian bowl, and a complete upperstone of a disk quern, fourteen inches in diameter, as well as a mortarium of first- to second-century type. $\mathrm{Mr}$. Winbolt points out that future excavation on the Causeway, which is being widened on both sides, might bring to light Roman material from the Wiggonholt site, which would lead to quite erroneous conclusions as to the relation of the Causeway to Stane Street. Local societies might well be at pains to record any such shifting of material from sites within their respective areas.

\section{British Museum (Natural History): Acquisitions}

THE most important recent zoological accession to the Zoological Department of the British Museum (Natural History) is perhaps a collection of mammals and birds made by Messrs. Charles and Edward G. Bird in the Mygybukta region of North East Green. land. The collection is of special interest since it contains examples in breeding plumage and chicks of birds well known in the British Isles in winter, such as the knot, sanderling, turnstone and brent goose. There are also specimens of the ptarmigan in breeding plumage, as well as young birds and small ducklings of the king eider - a rare visitor to Britain. Among the mammals are specimens of the lemming, skulls and skeletons of aretic foxes, and various seals. Another important acquisition to the Department is the mounted head of a chobe situtunga (Limnotragus spekei selousi) presented by Major Henry Abel Smith. This rare antelope is known only from about a dozen specimens and enjoys a distribution to the south of the Zambesi between the Chobe Swamps and Lake Ngami in Bechuanaland. Among the accessions to the Department of Entomology is the very valuable collection of butterflies formed by Major P. P. Graves in the Near East, particularly in Palestine, Asia Minor, Syria, the southern Balkans and Greece. This collection is made up of more than 9,000 specimens, and is particularly rich in material from historic localities which were extensively worked by German and Austrian collectors in the middle of the last century. 